\title{
HIV-1 subtype C envelope C2V5 characteristics; associations with markers of disease progression among 6 slowing progressing pediatric patients
}

\author{
Kerina Duri" ${ }^{*}$, Felicity Zvanyadza Gumbo², Knut Ivan Kristiansen ${ }^{3}$, Munyaradzi Paul Mapingure ${ }^{4}$, Simba Rusakaniko ${ }^{5}$, Fredrik Müller ${ }^{3}$ \\ and Babill Stray-Pedersen ${ }^{6}$ \\ *Correspondence: tkduri@yahoo.co.uk \\ ${ }^{1}$ Department of Immunology, University of Zimbabwe. \\ ${ }^{2}$ Department of Pediatrics and Child Health, University of Zimbabwe. \\ ${ }^{3}$ Department of Microbiology, University of Oslo and Oslo University Hospital, Rikshospitalet, Oslo, Norway. \\ ${ }^{4}$ Letten Foundation Research Centre, Harare, Zimbabwe. \\ ${ }^{5}$ Department of Community Medicine, University of Zimbabwe. \\ ${ }^{6}$ Division of Women and Children, Oslo University Hospital, Rikshospitalet and Institute of Clinical Medicine, \\ University of Oslo, Oslo, Norway.
}

\begin{abstract}
Background: HIV-1 gp120 envelope variable regions potential N-glycosylation sites (PNGs) and amino acid length polymorphisms have been shown to play pivotal roles in disease progression in spite of other studies demonstrating contradictory results.

Methods: Regression analysis was used to assess the association between changes in PNGs or amino acid sequence lengths of C2V5 region/sub-regions and disease progression as a function of HIV-1 RNA load or CD4\% among antiretroviral therapy naïve subtype C infected but slowly disease progressing children.

Results: Unit increases in amino acid sequence lengths within the V3 region was associated with a 5 unit increase in CD4\%, $\mathrm{p}=0.010$. Unit increases in PNGs within the C2V5 region, V3 and V5 sub-regions were associated with 3, 9 and 8 unit increases in CD4\%; $\mathrm{p}=0.041,0.040$ and 0.02 , respectively. Interestingly, a unit PNGs increase within the C4 sub-region correlated with a 1.2 million copies/ $\mathrm{ml}$ decrease in viral load, $\mathrm{p}=0.009$.

Conclusion: C4 sub-region PNGs may be influential in viral replications whilst amino acid length polymorphism within the V3 regions could be key in host immunological surveillance. However, bigger studies with more clones per sample are warranted to substantiate these preliminary findings and whether such observations are also true for the adult the population.
\end{abstract}

Keywords: HIV subtype C, C2V5 sequence lengths, potential N glycosylation sites, children

\section{Introduction}

Disease progression in HIV infection demonstrates interindividual variation due to the complex interplay between environmental, host genetic, immunologic and viral factors. Rapid HIV disease progression has been related to high maternal viral load, ineffectiveness of the cellular immune control, heterozygosity of host restrictive genes associated with delayed progression, timing of transmission including immaturity of the adaptive immune response of infants including viral characteristics [1-3]. Viral characteristics associated with slow HIV disease progression in pediatric patients remain poorly described and more over the little that is currently known comes from subtype B studies. Characterisation of HIV-1 env gene from slow progressors is not only important in understanding HIV-1 pathogenesis but is also fundamental in providing information on viral correlates of protection essential for effective vaccine design and development.

In the absence of antiretroviral therapy, most HIV-1 infected infants in Sub Saharan Africa progress to AIDS or death within two years of life [4]. Irrespective of the enhanced immune activation due to the heavy parasitic burden aggravated by nutritional deficiencies, recent studies have shown that a quarter of HIV-infected antiretroviral naïve African infants are "slow progressors", presenting for care for the first time during adolescence [5-7]. In Zimbabwe, an estimated 120000 children are living with HIV of which $3.4 \%$ are long term survivors of vertical transmission $[\mathbf{8}, 9]$. Despite being infected by the same mother, studies have shown that siblings have shown marked differences in the rate of disease progression [10] with in utero infected infants progressing more rapidly $[11,12]$. Children infected post-natally through breastfeeding have been shown to be slow progressors $[13,14]$. Studies have shown that the route and timing of infection alone are not predictive of disease progression in infected infants [15]. HIV-1 gp120 variable regions exhibit an unusual pattern with encoded amino acids (asparagine, serine, and threonine) that leads to the creation of new N-linked glycosylation sites, which helps the virus to escape from the immune pressure [16]. Potential N glycosylation sites (PNGs) glycans and amino acid length polymorphism have been shown to play essential roles in disease progression 
Duri et al. Virology Discovery 2013,

http://www.hoajonline.com/journals/pdf/2052-6202-1-4.pdf

doi: $10.7243 / 2052-6202-1-4$

Table 1. Siblings' demographics, virological, immunological parameters and clinical abnormalities.

\begin{tabular}{lcccccl}
\hline Sibling & Age (Years) & Sex & CD4 count & CD4 \% & Viral load Copies/mL & Abnormal clinical signs \\
\hline $2051^{\text {st }}$ & 5.3 & M & 3170 & 23 & 100110 & none \\
$2052^{\text {nd }}$ & 2 & F & 512 & 41.2 & 254676 & underweight \\
$3661^{\text {st }}$ & 3.9 & F & 197 & 25 & 138628 & Scabies, dysentery, TB \\
$3751^{\text {st }}$ & 3.7 & $\mathrm{~F}$ & 3156 & 30 & 3232925 & lymphadenopathy \\
$5671^{\text {st }}$ & 4.5 & M & 1849 & 19.5 & 1736 & T. capitis \\
$5672^{\text {nd }}$ & 1.5 & M & 1588 & 21.7 & 353418 & kwashiokor \\
\hline
\end{tabular}

$1^{\text {st. First sibling }}$

$2^{\text {nd: }}$ Second

with changes potentially affecting the capacity of the virus to replicate [17-19]. Studies have shown that at birth all HIV infected infants' envelope amino acid sequences are initially of the same length as the maternal ones with amino acid sequence length polymorphism observed from six months postpartum [20]. However, other studies have observed no clear trends in changes in neither the envelope PNGs nor median amino acid lengths with disease progression $[20,21]$. In that view we sought to determine HIV-1 env gp 120 sequence characteristics associated with pediatric disease progression assessed as a function of laboratory markers of CD4 percentage and HIV-1 RNA load.

\section{Methods}

\section{Study population and procedures}

Four index children (older/ first sibling) and two index child's siblings (younger or second siblings) from HIV-1 infected families labeled 205, 366, 375 and 567 constituted the study population. The index child in this study was defined as the first child to be recruited into our study. Two families, 205 and 567 had two subsequent biological children, the first and second siblings. All the children were HIV- 1 infected and none had received antiretroviral therapy at the time of sample collection. Consent was obtained from the respective pregnant mothers of each of the four families participating in the national PMTCT programme in peri urban Harare mother and child clinic who were known to be HIV-1 positive at 36 weeks gestations. Similar recruitment and procedures were followed as previously described for the mothers and infants [22]. Despite being encouraged to exclusively breastfeed during the first six months of life, all the infants were exposed to breast milk for at least nine months. First siblings' samples were collected at $60 \pm 10$ months of age as there were insufficient sample volumes from their respective first HIV positive samples. The first available HIV-1 positive sample was genotyped for the second siblings at about $15 \pm 3$ months. CD4 counts, viral load determination, nucleic acid extraction, PCR amplification, cloning and DNA sequencing methods for the HIV-1 env gp $120 \mathrm{C} 2 \mathrm{~V} 5$ region were done as previously described and so was subtype determination [23].

\section{Data analysis}

The 520 base pair nucleotide sequences were translated to amino acid sequence using the Gene Doc program. The amino acid sequences in their Fasta formats were entered into a glycosylation analysis site: $h t t p: / / w w w . h i v . l a n l . g o v /$ content/hiv-db/GLYCOSITE/glycosite, where PNGs along the sequences were marked and counted. Numbers of PNGs of $\mathrm{C} 2 \mathrm{~V} 5$ region and sub-regions were enumerated. Median and range values of sequence length and PNGs were calculated for child as previously described [24]. An average of two clones was done per sample. Sequences were aligned, translated, manually edited and separated into $\mathrm{C} 2, \mathrm{~V} 3, \mathrm{C} 3, \mathrm{~V} 4, \mathrm{C} 4$ and V5 sub-regions. Sequence sub-region lengths were determined and PNGs counted. Data were entered and analysed using Stata version 10. The number of PNGs and including sequence length polymorphisms of $\mathrm{C} 2 \mathrm{~V} 5$ and sub-regions were determined for each child. Regression analysis was used to investigate the association between PNGs or amino acid sequence lengths polymorphism of the C2V5 region/ sub-regions and viral load or CD4 \%. Student t-test was used to compare mean $\log _{10}$ viral load between the male and female children. Tests of statistical significance included the $95 \%$ confidence interval (CI) of relative risks; two sided $p$ values of less than 0.05 were considered statistically significant.

\section{Ethical consideration}

The study was approved by the Medical Research Council of Zimbabwe (MRCZ) and the Ethical Review Committee of Norway. Written consent to participate in the research study was obtained from the mothers on behalf of the minors. There was freedom to discontinue participating in the study at any given time without any prejudice. Mothers also consented to usage of blood samples of their children in future other HIV related researches.

\section{Results}

\section{Demography, clinical presentation}

Of the six children the 4 first siblings were about 50 months old whilst the two second siblings were about 20 months old. They were equally balanced in respect to gender but presented difference clinical abnormalities ranging from lymphadenopathy to Mycobacterium tuberculosis (TB) infection. See Table 1. Almost all of the parameters analyzed varied substantially from child to child, including CD4 count, CD4\%, and viral RNA load. The CD4\% of all the children 
Duri et al. Virology Discovery 2013,

Table 2. Relationship between PNGs, Amino acid lengths and viral load (copies/mL) in children.

\begin{tabular}{lcccc}
\hline HIV-1 Env & \multicolumn{2}{c}{ PNGs } & \multicolumn{2}{c}{ Amino Acid Length } \\
\hline Region & $\begin{array}{c}\text { Regression } \\
\text { coefficient }\end{array}$ & P value & $\begin{array}{c}\text { Regression } \\
\text { coefficient }\end{array}$ & P value \\
\hline C2 & 560544 & 0.299 & - & - \\
C3 & -56432 & 0.880 & -81751 & 0.446 \\
C4 & -1151683 & 0.009 & - & - \\
V3 & -483628 & 0.347 & 251305 & 0.328 \\
V4 & 158145 & 0.689 & 49551 & 0.659 \\
V5 & 298808 & 0.479 & 318280 & 0.003 \\
C2V5 & -65563 & 0.689 & 47901 & 0.294 \\
\hline
\end{tabular}

Table 3. Relationship between PNGs, amino acid length and CD4 \% in Children.

\begin{tabular}{lcccc}
\hline HIV-1 Env & \multicolumn{2}{c}{ PNGs } & \multicolumn{2}{c}{ Amino Acid Length } \\
\hline Region & $\begin{array}{c}\text { Regression } \\
\text { coefficient }\end{array}$ & P value & $\begin{array}{c}\text { Regression } \\
\text { coefficient }\end{array}$ & P value \\
\hline C2 & +5.323 & 0.229 & - & - \\
C3 & +4.10 & 0.171 & -1.121 & 0.197 \\
C4 & -4.326 & 0.277 & - & - \\
V3 & +8.283 & 0.040 & +4.983 & 0.010 \\
V4 & -0.584 & 0.858 & -1.231 & 0.172 \\
V5 & +7.621 & 0.025 & -0.709 & 0.425 \\
C2V5 & +2.590 & 0.041 & -0.3738 & 0.322 \\
\hline
\end{tabular}

ranged from $19.5 \%$ to $41 \%$. In general female children had higher copies of HIV-1 RNA viral load compared to their male counterparts, viral load $\log _{10} 5.6$ and $\log _{10} 4.6$ respectively, $\mathrm{p}=0.025$.

\section{Correlation between PNGs and viral load or CD4\%}

There was no clear relationship between children's PNGs within neither the $\mathrm{C} 2 \mathrm{~V} 5$ region nor $\mathrm{C} 2, \mathrm{C} 3, \mathrm{~V} 3, \mathrm{~V} 4$ including V5 sub-regions and viral load. However, each unit increase in PNGs within the C4 sub-region was associated with a 1.2 million copies decrease in viral load, $p=0.009$. This relationship remained statistically significant even after adjustment for potentially important confounders such as age and gender. For a unit increase in PNGs within the entire $\mathrm{C} 2 \mathrm{~V} 5$ region including the $\mathrm{V} 5$ and $\mathrm{V} 3$ sub-regions, the $\mathrm{CD} 4$ percentage increased by about 3,8 and 9 units $p=0.041,0.025$ and 0.040 respectively See Table 2 .

\section{Correlation between amino acid length polymorphism and viral load or CD4\%}

There were no statistically significant differences in the rate of CD4\% decline and subsequent amino acid length polymorphisms in all sub-regions except for the $\mathrm{V} 3$ region. Interestingly each unit increase in $\mathrm{V} 3$ amino acid length was associated with a 5 units increase in CD4\%, $p=0.010$, see Table 3. A unit increase in amino acid length within the V5 region was associated with 320000 copies increase in HIV-1
RNA load, $p=0.003$, otherwise no other statistically significant associations were observed in other sub-regions.

\section{Discussion}

Slowly progressing HIV-1 infected but treatment naïve pediatric patients afforded us the opportunity to assess the natural immune selection of env gene after years of infection. In this paper we assessed whether immunological progression and virological responses of HIV-1 subtype C correlated with viral env gp120 C2V5 region PNGs and amino acid length polymorphism. The Paediatric HIV-1 RNA load remains high during the first years of life, gradually declining slowly only after development of cytotoxic T Lymphocytes (CTL) response after the age of 6 months [25]. In our study, a unit increase in glycans was associated with decreases in viral load although a different picture was depicted by child 567 first sibling who surprising despite the fewer PNGs had the least viral load (1700 copies $/ \mathrm{mL}$ ) who interestingly was slightly over five years of age without treatment. This observation could probably be a case of attenuated HIV variants with low replicative capacity linked to non-progressive disease [26,27]. Against all odds this child had also T. capitis infection which under normal circumstances would be expected to enhance viral replication due to immune activation thereby facilitating a faster progression to AIDS $[\mathbf{2 8 , 2 9 ]}$. Slow progressing infants typically have virus with a low replicative capacity which may be the influence of viral attenuation the selection of Gag CD8 T-cell escape variants [30].

A contradictory trend was observed for $\mathrm{V} 5$ region amino acid length and viral load. This observation is complimenting recent findings which have demonstrated that increased sequence length and glycosylation in in the $\mathrm{V} 5$ region may collectively create steric hindrance that lowers binding affinity, thereby increasing resistance to neutralization [31]. A subtype $C$ study of a single Zambian HIV infected but slowly progressing infant showed that neither lengthening of the V1V5 domain nor the acquisition of glycosylation site were not always a component glycoprotein evolution in newly infected children [20]. Interestingly for the V3 region there was a positive correlation with both PNGs and amino acid length with CD4 \% increase. Except for sibling pair 567 amino acid lengths tended to increase with age of infection as shown amongst the first and second siblings. Compared to the second siblings, the rate of immunological progression was worse for the first siblings who have been infected for relatively longer periods compared to the first siblings. Interestingly, child 567 first sibling's mean amino acid length was not significantly different from that of other children with viral load in hundred thousands of RNA copies per $\mathrm{mL}$. Even more interesting was the comparison of measured parameters two the 567 sibling pairs of which the first sibling, 567-1 seemed to be doing much better than the second sibling, 567-2 based on the data presented in Table 1. Despite their 3 years age difference they had similar CD4 counts and CD4\%, 
yet differed by over $2 \log 10$ in viral load. Thus the older child was quite close to meeting the criteria for being considered an elite control. This is not surprising as disease progression is influenced by many other host genetics factors such as the genotype at the major histocompatibility complex class I loci, polymorphism in CCR5, SDF-1, apolipoprotein B mRNA editing enzyme catalytic polyprotein-like 3G( APOBEC3G), ring finger protein 39 and the zinc ribbon domain-containing genes [32-34]. Moreover other subtype $C$ studies have attributed slower disease progression to altered Nef protein functions [35]. Our children are generally slow progressors as all of them were infected post-natally through breast feeding as similarly described by others $[13,14]$. This timing of HIV infection could have a critical impact on the anti-HIV immune response as the immune system has been shown to undergo major changes during the postpartum period, shifting away from active acquisition of self-tolerance in utero towards defensive responses to antigens encountered postnatally [36].

The observation of slower HIV disease progression in African patients is in apparent contradiction with the observation that the typical rate of disease progression seems to be faster in Africa than among patients of European descent in industrialized countries $[37,38]$. Recent findings have shown that the lack of Duffy antigen receptor for chemokines (DARC) on the red blood cells of patients of African descent is associated with slower disease progression [39]. We have no data on DARC expression in our patients, although the DARC negative phenotype is almost universal in sub-Saharan Africa [39]. Given the substantial genetic diversity present in the quasispecies of chronically HIV infected patients the few sequences analyzed per child compounded by lack of longitudinal data are the major limitations. Despite the interesting preliminary findings the overall sample size is also the major challenge of this study. Thus larger studies are warranted with enough statistical power to infer more meaningful associations of the parameters investigated.

\section{Conclusion}

Sequencing of the HIV-1 subtype C envelope and assesment of PNGs is important as this may lead to identification of functional sites which can shed a little bit more light on correlations immunological and virological relevant sites with important implications in both drug and vaccine designs and development. C4, V3 and V5 regions prospective regions worth further exploration on a bigger prospective cohort.

\section{Competing interests}

The authors declare that they have no competing interests.

\section{Authors' contributions}

DK collected data, carried out the laboratory analysis and drafted the manuscript, GFZ collected data, KKI participated in laboratory analysis, MMP carried out data analysis and interpretation of results, RS supervised data analysis and interpretation of results, designing of the study, MF supervised laboratory analysis, SB participated in designing of the study. All authors read and corrected the final version of the manuscript.

Acknowledgement

We gratefully acknowledge the women and infants who participated in this study and the study support staff. The study was funded by The Letten Foundation, Oslo, Norway. Special mention goes to the Letten Foundation and Professor Letten herself for funding this study.

\section{Publication history}

Editor: Qingming Dong, University of Tennessee Health Science Center, USA.

EIC: Preet M Chaudhary, Keck School of Medicine USC, USA.

Received: 15-Feb-2013 Accepted: 29-Jul-2013

Published: 02-Aug-2013

\section{References}

1. Hazra R, Siberry GK and Mofenson LM. Growing up with HIV: children, adolescents, and young adults with perinatally acquired HIV infection. Annu Rev Med. 2010; 61:169-85. | Article | PubMed

2. Huang S, Dunkley-Thompson J, Tang Y, Macklin EA, Steel-Duncan J, Singh-Minott I, Ryland EG, Smikle M, Walker BD, Christie CD and Feeney ME. Deficiency of HIV-Gag-specific T cells in early childhood correlates with poor viral containment. J Immunol. 2008; 181:8103-11. | Article | PubMed Abstract | PubMed Full Text

3. Little K, Thorne C, Luo C, Bunders M, Ngongo N, McDermott P and Newell ML. Disease progression in children with vertically-acquired HIV infection in sub-Saharan Africa: reviewing the need for HIV treatment. Curr HIV Res. 2007; 5:139-53. | Article | PubMed

4. Prendergast $A$, Tudor-Williams $G$, Jeena $P$, Burchett $S$ and Goulder $P$. International perspectives, progress, and future challenges of paediatric HIV infection. Lancet. 2007; 370:68-80. | Article | PubMed

5. Marston M, Becquet R, Zaba B, Moulton LH, Gray G, Coovadia H, Essex M, Ekouevi DK, Jackson D, Coutsoudis A, Kilewo C, Leroy V, Wiktor S, Nduati $R$, Msellati P, Dabis F, Newell ML and Ghys PD. Net survival of perinatally and postnatally HIV-infected children: a pooled analysis of individual data from sub-Saharan Africa. Int J Epidemiol. 2011; 40:385-96 6. | Article | PubMed Abstract | PubMed Full Text

6. Ferrand RA, Munaiwa L, Matsekete J, Bandason T, Nathoo K, Ndhlovu CE, Munyati S, Cowan FM, Gibb DM and Corbett EL. Undiagnosed HIV infection among adolescents seeking primary health care in Zimbabwe. Clin Infect Dis. 2010; 51:844-51. | Article | PubMed

7. Walker AS, Mulenga V, Sinyinza F, Lishimpi K, Nunn A, Chintu C and Gibb DM. Determinants of survival without antiretroviral therapy after infancy in HIV-1-infected Zambian children in the CHAP Trial. J Acquir Immune Defic Syndr. 2006; 42:637-45. | Article | PubMed

8. Central Statistical Office (CSO) [Zimbabwe] and Macro Internatioanal Inc 2007. Zimbabwe demographic and health survey 2005-6. 2011. Calverton, Maryland, CSO and Macro International Inc. I Pdf

9. Prendergast $A$, Tudor-Williams $G$, Jeena $P$, Burchett $S$ and Goulder $P$. International perspectives, progress, and future challenges of paediatric HIV infection. Lancet. 2007; 370:68-80. | Article | PubMed

10. Ripamonti C, Leitner T, Lauren A, Karlsson I, Pastore A, Cavarelli M, Antonsson L, Plebani A, Fenyo EM and Scarlatti G. Biological and genetic evolution of HIV type 1 in two siblings with different patterns of disease progression. AIDS Res Hum Retroviruses. 2007; 23:1531-40. | Article | PubMed

11. Blanche S, Rouzioux C, Moscato ML, Veber F, Mayaux MJ, Jacomet C, Tricoire J, Deville A, Vial M, Firtion $G$ and et al. A prospective study of infants born to women seropositive for human immunodeficiency virus type 1. HIV Infection in Newborns French Collaborative Study Group. N Engl J Med. 1989; 320:1643-8. | Article | PubMed

12. Mayaux MJ, Burgard M, Teglas JP, Cottalorda J, Krivine A, Simon F, Puel J, Tamalet C, Dormont D, Masquelier B, Doussin A, Rouzioux C and Blanche $S$. Neonatal characteristics in rapidly progressive perinatally acquired 
Duri et al. Virology Discovery 2013,

http://www.hoajonline.com/journals/pdf/2052-6202-1-4.pdf

doi: $10.7243 / 2052-6202-1-4$

HIV-1 disease. The French Pediatric HIV Infection Study Group. JAMA. 1996; 275:606-10. | Article | PubMed

13. Marinda E, Humphrey JH, Iliff PJ, Mutasa K, Nathoo KJ, Piwoz EG, Moulton LH, Salama P and Ward BJ. Child mortality according to maternal and infant HIV status in Zimbabwe. Pediatr Infect Dis J. 2007; 26:519-26. | Article | PubMed

14. Zijenah LS, Moulton LH, Iliff P, Nathoo K, Munjoma MW, Mutasa K, Malaba L, Zvandasara P, Ward BJ and Humphrey J. Timing of mother-tochild transmission of HIV-1 and infant mortality in the first 6 months of life in Harare, Zimbabwe. AIDS. 2004; 18:273-80. | Article | PubMed

15. Zhang H, Hoffmann F, He J, He X, Kankasa C, Ruprecht R, West JT, Orti G and Wood C. Evolution of subtype C HIV-1 Env in a slowly progressing Zambian infant. Retrovirology. 2005; 2:67. | Article | PubMed Abstract | PubMed Full Text

16. Bosch ML, Andeweg AC, Schipper R and Kenter M. Insertion of $\mathrm{N}$-linked glycosylation sites in the variable regions of the human immunodeficiency virus type 1 surface glycoprotein through AAT triplet reiteration. J Virol. 1994; 68:7566-9. | Article | PubMed Abstract | PubMed Full Text

17. Yoo PD, Shwen Ho Y, Ng J, Charleston M, Saksena NK, Yang P and Zomaya AY. Hierarchical kernel mixture models for the prediction of AIDS disease progression using HIV structural gp120 profiles. BMC Genomics. 2010; 11 Suppl 4:S22. | Article | PubMed Abstract | PubMed Full Text

18. Shioda T, Oka S, Xin X, Liu H, Harukuni R, Kurotani A, Fukushima M, Hasan MK, Shiino T, Takebe $Y$, Iwamoto $A$ and Nagai $Y$. In vivo sequence variability of human immunodeficiency virus type 1 envelope gp120: association of V2 extension with slow disease progression. J Virol. 1997; 71:4871-81. | Article | PubMed Abstract | PubMed Full Text

19. Hill MD, Lorenzo $E$ and Kumar A. Changes in the human immunodeficiency virus $\mathrm{V} 3$ region that correspond with disease progression: a meta-analysis. Virus Res. 2004; 106:27-33. | Article | PubMed

20. Zhang H, Hoffmann F, He J, He X, Kankasa C, West JT, Mitchell CD, Ruprecht RM, Orti G and Wood C. Characterization of HIV-1 subtype C envelope glycoproteins from perinatally infected children with different courses of disease. Retrovirology. 2006; 3:73. | Article | PubMed Abstract | PubMed Full Text

21. Tso FY, Hoffmann FG, Tully DC, Lemey P, Rasmussen RA, Zhang H, Ruprecht RM and Wood C. A comparative study of HIV-1 clade C env evolution in a Zambian infant with an infected rhesus macaque during disease progression. AIDS. 2009; 23:1817-28. | Article | PubMed Abstract | PubMed Full Text

22. Gumbo FZ, Kandawasvika GQ, Duri K, Mapingure MP, Kurewa NE, Nathoo K, Rusakaniko S, Chirenje MZ and Stray-Pedersen B. Reduced HIV transmission at subsequent pregnancy in a resource-poor setting. Trop Doct. 2011; 41:132-5. | Article | PubMed Abstract | PubMed Full Text

23. Duri K, Soko W, Gumbo F, Kristiansen K, Mapingure M, Stray-Pedersen B and Muller F. Genotypic analysis of human immunodeficiency virus type 1 env V3 loop sequences: bioinformatics prediction of coreceptor usage among 28 infected mother-infant pairs in a drug-naive population. AIDS Res Hum Retroviruses. 2011; 27:411-9. | Article | PubMed

24. Derdeyn CA, Decker JM, Bibollet-Ruche F, Mokili JL, Muldoon M, Denham $\mathrm{SA}$, Heil ML, Kasolo F, Musonda R, Hahn BH, Shaw GM, Korber BT, Allen $\mathrm{S}$ and Hunter E. Envelope-constrained neutralization-sensitive HIV-1 after heterosexual transmission. Science. 2004; 303:2019-22. | Article | PubMed

25. Pillay T and Phillips RE. Adaptive evolution in perinatal HIV-1. Best Pract Res Clin Obstet Gynaecol. 2005; 19:211-29. | Article I PubMed

26. Deacon NJ, Tsykin A, Solomon A, Smith K, Ludford-Menting M, Hooker DJ, McPhee DA, Greenway AL, Ellett A, Chatfield C, Lawson VA, Crowe S, Maerz A, Sonza S, Learmont J, Sullivan JS, Cunningham A, Dwyer D, Dowton $D$ and Mills $J$. Genomic structure of an attenuated quasi species of HIV-1 from a blood transfusion donor and recipients. Science. 1995; 270:988-91. | Article | PubMed

27. Quinones-Mateu ME, Ball SC, Marozsan AJ, Torre VS, Albright JL, Vanham G, van Der Groen G, Colebunders RL and Arts EJ. A dual infection/ competition assay shows a correlation between ex vivo human immunodeficiency virus type 1 fitness and disease progression. $J$ Virol.
2000; 74:9222-33. | Article | PubMed Abstract | PubMed Full Text

28. Lawn SD, Butera ST and Folks TM. Contribution of immune activation to the pathogenesis and transmission of human immunodeficiency virus type 1 infection. Clin Microbiol Rev. 2001; 14:753-77. | Article | PubMed Abstract | PubMed Full Text

29. Borkow $G$ and Bentwich $Z$. Chronic immune activation associated with chronic helminthic and human immunodeficiency virus infections: role of hyporesponsiveness and anergy. Clin Microbiol Rev. 2004; 17:101230. | Article | PubMed Abstract | PubMed Full Text

30. Prado JG, Honeyborne I, Brierley I, Puertas MC, Martinez-Picado J and Goulder PJ. Functional consequences of human immunodeficiency virus escape from an HLA-B*13-restricted CD8+ T-cell epitope in p1 Gag protein. J Virol. 2009; 83:1018-25. | Article | PubMed Abstract | PubMed Full Text

31. Guo D, Shi, Arledge et al. V5 region in the HIV-1 envelope glycoproteindetermines viral sensitivity to the broadly neutralizing monoclonal antibody VRC01. Retrovirology. 2012; 9:46. | Article

32. Carrington $M$ and $O$ 'Brien SJ. The influence of HLA genotype on AIDS. Annu Rev Med. 2003; 54:535-51. | Article | PubMed

33. Fauci AS. Resistance to HIV-1 infection: it's in the genes. Nat Med. 1996; 2:966-7. | Article | PubMed

34. An P, Bleiber G, Duggal P, Nelson G, May M, Mangeat B, Alobwede I, Trono D, Vlahov D, Donfield S, Goedert JJ, Phair J, Buchbinder S, O'Brien SJ, Telenti A and Winkler CA. APOBEC3G genetic variants and their influence on the progression to AIDS. J Virol. 2004; 78:11070-6. | Article | PubMed Abstract | PubMed Full Text

35. Tzitzivacos DB, Tiemessen CT, Stevens WS and Papathanasopoulos MA. Viral genetic determinants of nonprogressive HIV type 1 subtype C infection in antiretroviral drug-naive children. AIDS Res Hum Retroviruses. 2009; 25:1141-8. | Article | PubMed

36. Howard JG and Mitchison NA. Immunological tolerance. Prog Allergy. 1975; 18:43-96. | Article | PubMed

37. Lawn SD. AIDS in Africa: the impact of coinfections on the pathogenesis of HIV-1 infection. J Infect. 2004; 48:1-12. | Article | PubMed

38. Bentwich Z, Kalinkovich A and Weisman Z. Immune activation is a dominant factor in the pathogenesis of African AIDS. Immunol Today. 1995; 16:187-91. | Article | PubMed

39. He W, Neil S, Kulkarni H, Wright E, Agan BK, Marconi VC, Dolan MJ, Weiss RA and Ahuja SK. Duffy antigen receptor for chemokines mediates trans-infection of HIV-1 from red blood cells to target cells and affects HIV-AIDS susceptibility. Cell Host Microbe. 2008; 4:52-62. | Article PubMed Abstract | PubMed Full Text

\section{Citation:}

Duri K, Gumbo FZ, Kristiansen KI, Mapingure MP, Rusakaniko S, Müller F and Stray-Pedersen B. HIV-1 subtype C envelope C2V5 characteristics; associations with markers of disease progression among 6 slowing progressing pediatric patients. Virol Discov. 2013; 1:4.

http://dx.doi.org/10.7243/2052-6202-1-4 